\title{
SUSTAINABLE GREEN CONSTRUCTION MANAGEMENT: SCHEDULE PERFORMANCE AND IMPROVEMENT
}

\author{
Bon-Gang HWANG ${ }^{\mathrm{a}}$, Lay Peng LEONG ${ }^{\mathrm{b}}$, Young-Ki HUH ${ }^{\mathrm{c}}$ \\ ${ }^{a}$ School of Design \& Environment, National University of Singapore, 157766 Singapore \\ ${ }^{b}$ Executive, Cost Control, EC Harris Singapore Pte Ltd, 089315 Singapore \\ 'School of Architecture, Pusan National University, Busan, 609-735 South Korea
}

Received 25 January 2012; accepted 20 May 2012

\begin{abstract}
Over the last few years, the green building movement in Singapore has leaped bountifully. While environmental sustainability for greener construction has been emphasized, rare research has been conducted to analyze performance of green construction projects. As a result, this study aims to address schedule performance of green building construction projects and to provide some recommendations that may improve the targeted performance. To achieve this objective, a questionnaire was developed and the responses from 30 companies were analysed, and interviews with 6 project managers were conducted to further supplement and substantiate the survey results. The analysis reported that green building projects required an average of $8 \%$ more time than traditional building projects of similar size and characteristics. In addition, on average, these projects were delayed by $4.8 \%$ when compared with their as-planned schedules. Lastly, a list of recommendations was also introduced, aiming to ameliorate the schedule performance. This study will offer a benchmark for the industry to gauge the overall duration and performance of green building construction projects.
\end{abstract}

Keywords: green building, construction, schedule, performance, sustainability, Singapore.

Reference to this paper should be made as follows: Hwang, B.-G.; Leong, L. P.; Huh, Y.-K. 2013. Sustainable green construction management: schedule performance and improvement, Technological and Economic Development of Economy 19(Supplement 1): S43-S57.

JEL Classification: L74, O22, O32, O53.

\section{Introduction}

Building construction companies from various regions around the world have integrated green concept into their construction plans to mitigate the impacts to the environment (Hwang, Tan 2012). Singapore has also shifted its focus to making sustainable development

Corresponding author Young-Ki HUH

E-mail:ykhuh@pusan.ac.kr 
a key national priority as well (Building and Construction Authority 2009; Hwang, Ng 2013; Kua 2011; Singapore Green Building Council 2009). Since the launch of the Green Mark Scheme in 2005, the number of green mark certified buildings in Singapore has increased to about 440 from the mere 17 green mark certified buildings in 2005 (The Business Times 2010). Above and beyond the Green Mark Scheme developed by the Building and Construction Authority (BCA) to promote environmental sustainability in buildings, BCA had also formulated the $1^{\text {st }}$ and $2^{\text {nd }}$ Green Building Masterplan together with other efforts to thrust forward in developing more green buildings in Singapore. By year 2030, through BCA's $2^{\text {nd }}$ Green Building Masterplan, the Inter-Ministerial Committee on Sustainable Development (IMCSD) targets to have at least $80 \%$ of the buildings in Singapore to achieve the BCA Green Mark Certified rating (Building and Construction Authority 2009). Furthermore, in order to intensify the efforts in speeding up the development of green buildings in Singapore, the Code for Environmental Sustainability of Buildings incorporated the Green Mark Scheme, which requires all new building developments and major renovations which are over 2000 meters square in size to achieve minimum Green Mark certification in 2008 (Building and Construction Authority 2008).

Male (1988) argued that projects that are completed on time can be an indicator of an efficient construction industry. Positive construction time performance can ensure that a project can be completed within the stipulated time or earlier and provide the project owner with a higher opportunity to generate revenue at an earlier stage. While many researchers have performed analyses on the schedule performance of traditional construction projects, there has been little research focused on the schedule performance of green building construction projects. Therefore, this study aims to: (1) compare schedule performance of green and traditional building construction projects; and (2) provide some recommendations to improve schedule performance of green building projects. The analysis performed in this study identifies how much less/more time green building construction saves/spends over traditional building construction. Also, as there is rare reference point to gauge the schedule performance of green building construction projects, this study acts as a guide for the construction industry players to benchmark the time taken to construct green building projects in comparison with traditional building projects. Subsequently, this study can contribute to the building and construction industry by strengthening players' awareness and commitment towards sustainable management of green project schedule performance.

\section{Background}

According to Li et al. (2011) the negative environmental impacts of traditional building have attracted more attention to green buildings, resulting in an increasing number of studies on the project delivery of such building. The construction of green building is part of sustainable construction. According to Kibert (2008), sustainable construction addresses the ecological, social and economic issues of a building in the context of its community. Sustainable construction is applied throughout the entire life cycle of construction, from preconstruction to disposal of the building. Such construction aimed to reduce the impact of the construction 
practice on the environment through its planning and managing of a construction project complying with the contract document (Glavinich 2008).

Since the inception of Green Mark Scheme together with the $1^{\text {st }}$ and $2^{\text {nd }}$ Green Building Masterplan, Singapore has experienced a concerted shift towards the development of green buildings (Tobias 2010). The sharp growth in the number of BCA Green Mark Certified new buildings in 2007 is an evident success of the BCA's 1st Green Building Masterplan which was launched in 2006 (Building and Construction Authority 2009). The thrust towards more buildings being certified with Green mark has grown beyond Singapore to overseas such as Thailand, Vietnam, Indonesia, and China (Building and Construction Authority 2009; Nguyen et al. 2004; Ogunlana et al. 1996; Zhang et al. 2011). At present, statistics from the BCA green mark webpage revealed that there are a total of 326 green mark certified buildings in Singapore where 52 buildings are awarded with green mark platinum, 36 green mark gold ${ }^{\text {plus }}$ certified, 134 green mark gold certified and 104 green mark certified buildings (Building and Construction Authority 2010).

Korkmaz et al. (2010a) argued that owner commitment; project delivery system, project team procurement, contract conditions, design integration, project team characteristics, and construction process might affect schedule, cost, quality, and sustainable performance of green buildings and by managing these non-technical aspects, green buildings can be delivered successfully. This result is along with the findings of Enache-Pommer and Horman (2009), which identified the top three attributes: owner commitment, expertise on sustainable delivery, and early timing of sustainable objectives in the building delivery of green hospitals. Furthermore, Li et al. (2011) summarized 19 specific success factors for managing green building projects into five major components, namely, human resourceoriented factors, technical and innovation-oriented factor, support from designers and senior management, project manager's competence, and coordination of designers and contractors.

It has been identified that higher cost premium of green buildings would be one of critical barriers against active implementation of green concept and technologies to building projects (Tagaza, Wilson 2004; Hwang, Tan 2012). According to Zhang et al. (2011), Global Green Building Trends study, released in 2008, reported that of the over 700 construction professionals who responded to the survey, $80 \%$ cited "higher first costs" as an obstacle to green building (Kats 2010). Similarly, planning that involves schedules of green buildings tends to be affected by some specific features of green development.

Among various success factors that have identified by previous studies such as Fortune and White (2006), Hwang and Lim (2013), Hwang et al. (2013), Isik et al. (2009), Iyer and Jha (2006) and Lapinski et al. (2006), intensive construction planning and scheduling are one of the distinctive characteristics of green building construction, and green requirements need to be well addressed and reflected in execution plans and construction schedules to avoid any impediment (Glavinich 2008). As noted by GreenBiz Group (2005), the design and construction process of green building construction usually takes longer than traditional building construction. This might be due to the reason that project team members require more time to be familiar with and implement unique green building practices. Design can be more complicated than that of a conventional building due to the evaluation of alternative 
materials and systems (Hwang, Ng 2013). Kats et al. (2003) and Kats (2010) also supported that the design process of green building construction generally takes longer than traditional design process. Design documents are required to be more comprehensive and more time is necessary for architectural and engineering designs to integrate green building features. As a result, green building construction entails a more holistic and integrated approach for its design (Korkmaz et al. 2010b) and may result in increase of project schedule and cost (Glavinich 2008; Hwang, Ng 2013; Kats et al. 2003; Kibert 2008).

Green requirements also affect the schedule of procurement, construction, and commissioning (CIRIA 2001; Glavinich 2008; Choi 2009). Contractors have to ensure that materials, equipment, devices, and systems specific to green construction should be delivered as planned so as not to affect construction activities and schedule. Also, green requirements and constraints can have a great influence on construction phase as well. For example, HVAC ducts are usually mounted before a building under construction is enclosed. However, in green building construction, to prevent any dust and moisture contamination, the building is enclosed before installation of HVAC ducts (Glavinich 2008). As such, green requirements may pose an impact on the construction schedule and such requirements are needed to be indicated in the schedule to prevent any problems causing project delay.

Commissioning and closing out of green building projects is more complicated than that of conventional projects (Glavinich 2008). This is especially so when clients wish to attain third party green certification such as LEED and Green Mark. Also, there is a responsibility to impart knowledge of green building systems to new facilities management teams and end users to maintain the constructed facility (CIRIA 2001). As a result, the time to be spent in commissioning and closing out can be increased, affecting the entire duration of green construction projects.

With consideration of these unique characteristics of green construction, schedule performance of green building projects and its performance has been of interest. Although there have been several researches carried out to evaluate schedule performance of traditional construction projects, there is limited literature that has explored the areas mentioned above. As a result, this study tries to fill the gap by analyzing the responses from a questionnaire survey and interviews with industry experts.

\section{Methodology and data presentation}

Having conducted a comprehensive literature review of which the result was summarized in the previous section, a survey questionnaire was developed as input from industry practitioners were required to ensure that this study can represent the overall green building construction position. The main purpose of the survey was to observe how schedule performance of green building construction projects differs from traditional building projects. In addition, it intended to produce some recommendations which would be useful to enhance green construction schedule performance. The questionnaire was composed of four sections: (1) the profile of the participating companies and respondents; (2) the information of traditional and green building projects performed by the companies; (3) the assessment of schedule performance of green building projects; and (4) the solutions for improving green 
building schedule performance. More details of the questions in the survey are explained in the following section, in conjunction with the analysis results.

A total of 100 questionnaires were sent out with reference to the list made available by the directories of the BCA registered contractors and licensed builders, BCA green mark architectural firms, and Singapore Institute of Surveyors and Valuers. As the BCA green mark scheme commenced in 2005, the target of the survey was the companies that had experience in both green and traditional projects performed in years of 2005 to 2010. As a result of the survey, 30 completed questionnaires were returned and analyzed (Response Rate $=30 \%$ ). 30 respondents that represented their companies participated in the survey, based on the projects that their companies performed during the given timeframe. Due to confidentiality restrictions with the participating companies, the direct collection of individual project performance data was restricted while the respondents reported only aggregated data at the company level. Tables 1 and 2 summarize the profiles of the companies, respondents, and projects.

Table 1. Profile of companies and respondents

\begin{tabular}{|c|c|c|c|c|c|c|c|c|c|c|}
\hline \multirow{3}{*}{\multicolumn{2}{|c|}{ Characteristics }} & \multicolumn{8}{|c|}{ Years of experience } & \multirow{3}{*}{$\begin{array}{l}\text { Total } \\
(\mathrm{N}= \\
30)\end{array}$} \\
\hline & & \multicolumn{2}{|c|}{1 to 2 years } & \multicolumn{2}{|c|}{2 to 3 years } & \multicolumn{2}{|c|}{3 to 4 years } & \multicolumn{2}{|c|}{$>4$ years } & \\
\hline & & C.I & $\mathrm{G}$ & C.I & $\mathrm{G}$ & C.I & $G$ & C.I & G & \\
\hline \multirow{5}{*}{ 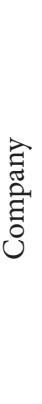 } & Construction & 0 & 2 & 0 & 3 & 0 & 4 & 18 & 9 & $\begin{array}{c}18 \\
(60 \%)\end{array}$ \\
\hline & Consulting & 0 & 0 & 0 & 0 & 0 & 1 & 5 & 4 & $\begin{array}{c}5 \\
(16.67 \%)\end{array}$ \\
\hline & Development & 0 & 0 & 0 & 0 & 0 & 1 & 3 & 2 & $\begin{array}{c}3 \\
(10 \%)\end{array}$ \\
\hline & $\begin{array}{l}\text { Quantity } \\
\text { Surveying }\end{array}$ & 0 & 0 & 0 & 0 & 0 & 0 & 4 & 4 & $\begin{array}{c}4 \\
(13.33 \%)\end{array}$ \\
\hline & Total & $\begin{array}{c}0 \\
(0 \%)\end{array}$ & $\begin{array}{c}2 \\
(6,6 \%)\end{array}$ & $\begin{array}{c}0 \\
(0 \%)\end{array}$ & $\begin{array}{c}3 \\
(10 \%)\end{array}$ & $0 \%$ & $\begin{array}{c}6 \\
(20 \%)\end{array}$ & $\begin{array}{c}30 \\
(100 \%)\end{array}$ & $\begin{array}{c}20 \\
(63,33 \%)\end{array}$ & $\begin{array}{c}30 \\
(100 \%)\end{array}$ \\
\hline \multirow{4}{*}{ 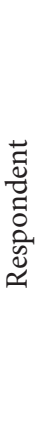 } & $\begin{array}{l}\text { Project } \\
\text { Manager/ } \\
\text { Construction } \\
\text { Manager }\end{array}$ & 0 & 3 & 0 & 3 & 0 & 5 & 18 & 7 & $18(60 \%)$ \\
\hline & $\begin{array}{l}\text { Project Di- } \\
\text { rector/Higher } \\
\text { Management }\end{array}$ & 0 & 0 & 0 & 1 & 0 & 3 & 4 & 0 & $\begin{array}{c}4 \\
(13.33 \%)\end{array}$ \\
\hline & $\begin{array}{l}\text { Projecr Per- } \\
\text { sonnel }\end{array}$ & 0 & 0 & 0 & 1 & 1 & 2 & 7 & 5 & $\begin{array}{c}8 \\
(26.67 \%)\end{array}$ \\
\hline & Total & $\begin{array}{c}0 \\
(0 \%)\end{array}$ & $\begin{array}{c}3 \\
(10 \%)\end{array}$ & $\begin{array}{c}0 \\
(0 \%)\end{array}$ & $\begin{array}{c}5 \\
(16.67 \%)\end{array}$ & $\begin{array}{c}1 \\
(3.33 \%)\end{array}$ & $\begin{array}{c}10 \\
(33.33 \%)\end{array}$ & $\begin{array}{c}29 \\
(96.67 \%)\end{array}$ & $\begin{array}{c}12 \\
(40 \%)\end{array}$ & $\begin{array}{c}30 \\
(100 \%)\end{array}$ \\
\hline
\end{tabular}

C.I refers to years of experience in construction industry;

$\mathrm{G}$ refers to years of experience in green building construction;

Higher Management includes Executive president, Project Director, General Manager and Managing Director; Project Personnel includes Project Engineers, Construction Engineers, and Quantity Surveyors. 
Table 2. Profile of projects

\begin{tabular}{|c|c|c|c|c|c|}
\hline & \multirow{2}{*}{ Characteristics } & \multicolumn{2}{|c|}{ Traditional Projects } & \multicolumn{2}{|c|}{ Green Projects } \\
\hline & & No. & $\%$ & No. & $\%$ \\
\hline \multirow{3}{*}{ 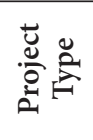 } & Commercial & 48 & 21.81 & 28 & 29.17 \\
\hline & Residential & 91 & 41.36 & 21 & 21.88 \\
\hline & Educational & 81 & 36.81 & 47 & 48.96 \\
\hline \multirow{4}{*}{ 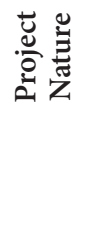 } & New Construction & 184 & 83.63 & 93 & 96.88 \\
\hline & Addition \& Aliteration & 36 & 16.36 & 3 & 3.12 \\
\hline & Less than $\$ 5 \mathrm{M}$ & 32 & 14.54 & 3 & 3.13 \\
\hline & $\begin{array}{l}\$ 5 \mathrm{M} \text { to less than } \\
\$ 10 \mathrm{M}\end{array}$ & 6 & 2.72 & 8 & 8.33 \\
\hline \multirow{5}{*}{ 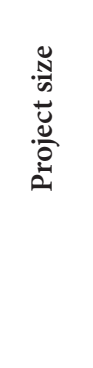 } & $\begin{array}{l}\$ 10 \mathrm{M} \text { to less than } \\
\$ 20 \mathrm{M}\end{array}$ & 35 & 15.90 & 6 & 6.25 \\
\hline & $\begin{array}{l}\$ 20 \mathrm{M} \text { to less than } \\
\$ 30 \mathrm{M}\end{array}$ & 33 & 15.00 & 13 & 13.54 \\
\hline & $\begin{array}{l}\$ 30 \mathrm{M} \text { to less than } \\
\$ 40 \mathrm{M}\end{array}$ & 15 & 6.81 & 16 & 16.67 \\
\hline & $\begin{array}{l}\$ 40 \mathrm{M} \text { to less than } \\
\$ 50 \mathrm{M}\end{array}$ & 27 & 12.27 & 18 & 18.75 \\
\hline & $\$ 50 \mathrm{M}$ and Above & 72 & 32.72 & 32 & 33.33 \\
\hline Total & & 220 & 100 & 96 & 100 \\
\hline
\end{tabular}

In addition to the survey, interviews with industry experts were conducted to further supplement and substantiate the survey results. This study was able to engage 6 project managers who have more than 3 years of experience in managing green building construction projects that had been awarded Green Mark Gold ${ }^{\text {Plus }}$ and Platinum. The analysis results presented in the following section were reviewed by the interviewees. Their shared views and experiences provided deep insights and understanding with regard to how performance of green construction would be like and differ from traditional construction. The interviewees also facilitated in proposing recommendations to improve schedule performance of green building projects.

\section{Data analysis and discussions}

\subsection{Duration of green building construction projects}

The respondents were first asked to provide the percentage of additional time required by green building projects. All the respondents agreed that green building projects took more time to complete when compared to similar types of traditional projects, and the average of the additional time taken was about $8 \%$ of the entire duration of the traditional building projects considered. This is in line with the findings of Glavinich (2008), which stated that green building construction projects would take a longer period to complete. 
Furthermore, as shown in Table 3, the survey result revealed that design development of green building projects took $17.15 \%$ more time than that of traditional projects. Planning and feasibility studies also required additional time of 15.7\%. According to Kubba (2010), green buildings are progressively incorporating more advanced and intricate systems of interacting elements. Furthermore, as mentioned by the project managers interviewed for this study, during the design development stage, greater efforts are made to ensure that all the green features are incorporated into design items, and confirmation on the design items is critical. Also, design consultants may require more time to convince the client to adopt a particular green system.

For planning and feasibility study of green projects, it is necessary to better understand green technologies to be used, which may be relatively new to the project team members. Some interviewees reported that most of the green technologies are imported from overseas and to ensure its compatibility and performance in the local context, numerous tests should be conducted. As a result, more time needs to be allocated to the planning and feasibility stage.

Furthermore, 'Selection of Project Team' was ranked third as shown in Table 3, indicating that this phase required $14.20 \%$ more time than that of traditional projects. This might be because project members to involve green projects need to have appropriate knowledge and experience in green technologies. To select right team members and to organize an optimized project team, rigorous selection procedures with a set of qualification criteria should be developed and implemented even if more time would be taken.

The analysis results discussed above were also supplemented by analysing the impact of the 7 phases, which are listed in Table 3, on entire schedule performance of green construction projects. Assuming that the phases required more time may have a stronger impact on project schedule performance, the survey asked the respondents to rank the level of relative significance of the phases, with 1 being most significant and 7 being least significant. The analysis revealed that the design development stage had the highest impact on schedule performance of green projects with mean rank of 2.23. In addition, the schematic design (Mean Rank $=3.10)$ and the planning and feasibility study (Mean Rank = 3.43) were ranked second

Table 3. Green project duration and schedule impact

\begin{tabular}{|c|c|c|c|c|}
\hline \multirow[t]{2}{*}{ Project Phase } & \multicolumn{2}{|c|}{$\begin{array}{l}\text { Additional Duration of Green } \\
\text { Project (\% of Traditional } \\
\text { Project Duration) }\end{array}$} & \multicolumn{2}{|c|}{$\begin{array}{c}\text { Impact on Schedule } \\
\text { Performance of Green Project }\end{array}$} \\
\hline & Mean & S. D. & Mean Rank & S. D. \\
\hline $\begin{array}{l}\text { Planning and Feasibility } \\
\text { Studies }\end{array}$ & 15.70 & 7.07 & 3.43 & 2.25 \\
\hline Selection of Project Team & 14.20 & 8.18 & 4.30 & 2.31 \\
\hline Schemetic Development & 9.62 & 7.22 & 3.10 & 1.13 \\
\hline Design Development & 17.15 & 7.15 & 2.23 & 1.31 \\
\hline Tender Document & 9.37 & 6.72 & 4.70 & 1.09 \\
\hline Construction & 12.20 & 7.93 & 4.30 & 1.56 \\
\hline $\begin{array}{l}\text { Closing Out and Commis- } \\
\text { sioning }\end{array}$ & 3.77 & 2.58 & 5.93 & 1.74 \\
\hline
\end{tabular}


and third, respectively. Based on these results, it could be deduced that project planning, feasibility studies, design development and schematic design need to be adequately managed to produce good schedule performance of green construction projects.

\subsection{Difficulty in meeting as-planned schedule}

The next question included in the survey asked the respondents to rate the difficulty in meeting the targeted schedule of green construction projects, with a scale of 1 being least difficult to 5 being 'most difficult. As shown in Table 4, majority of the respondents were in opinion that the difficulty of following as-planned schedule for both traditional (Mean = $3.367 ; \mathrm{SD}=1.189$ ) and green building projects (Mean $=3.667 ; \mathrm{SD}=1.124$ ) were somewhat similar. In order to see if the mean difference was statistically significant, the paired samples $\mathrm{t}$-test was conducted and the p-value was 0.001 , indicating that it is indeed more difficult for green projects to adhere to their as-planned schedule.

Table 4. Difficulty in meeting targeted schedule

\begin{tabular}{llccc}
\hline \multicolumn{1}{c}{ Variable } & Mean & N & $\begin{array}{c}\text { Std. } \\
\text { Deviation }\end{array}$ & $\begin{array}{c}\text { T-test } \\
(\mathbf{p} \text {-value })\end{array}$ \\
\cline { 1 - 2 } $\begin{array}{l}\text { Difficulty in meeting target- } \\
\text { ted schedule (Traditional) }\end{array}$ & 3.367 & 30 & 1.189 & \\
\cline { 1 - 2 } $\begin{array}{l}\text { Difficulty in meeting target- } \\
\text { ted schedule (Green) }\end{array}$ & 3.667 & 30 & 1.124 & \\
\hline
\end{tabular}

The project managers interviewed for this study commented that tools and systems being used for schedule management of green projects would not differ from those for traditional building projects. However, since green building projects would be more intricate, meeting asplanned schedule might be more laborious. For example, when new technologies and control systems need to be used to meet specific requirements of a green construction project, it is difficult to accurately estimate duration of the related activities. This may cause contractors in charge of the activities to easily go over the deadlines set by the estimation, resulting in schedule overrun of the entire project. As a result, the next section discusses the result of further analysis on the schedule overrun of green building projects.

\subsection{Schedule overrun of green building construction projects}

In order to identify schedule performance of green building projects, the frequency and the percentage of schedule overrun were analyzed, and Table 5 presents the summary of the analysis results.

The respondents were first required to report the frequency of green building projects completed later than as-planned schedule. As shown in Table 5, 50\% of the respondents (15) indicated that half of the green building projects that their companies performed were completed behind their planned schedule. On average, the frequency of schedule overrun of green building projects was approximately $43 \%$, indicating that about 4 out of 10 green projects that they had performed experienced schedule overrun. This probability can be considerably 
Table 5. Schedule overrun of green building construction projects

\begin{tabular}{|c|c|c|c|c|c|c|c|c|c|}
\hline \multicolumn{5}{|c|}{$\begin{array}{c}\text { Freaquency of Schedule Overrun } \\
\text { of Green Building Construction } \\
\text { Projects }\end{array}$} & \multicolumn{5}{|c|}{$\begin{array}{c}\text { Schedule of Overrun of Green Building } \\
\text { Construction Projects (\% of Planned } \\
\text { Schedule) }\end{array}$} \\
\hline Scale & $\begin{array}{l}\text { No. of } \\
\text { Res- } \\
\text { pon- } \\
\text { dents }\end{array}$ & $\%$ & $\begin{array}{c}\text { Mean, } \\
\%\end{array}$ & S. D. & $\begin{array}{c}\text { Scale, } \\
\%\end{array}$ & $\begin{array}{l}\text { No. of } \\
\text { Res- } \\
\text { pon- } \\
\text { dents }\end{array}$ & $\%$ & $\begin{array}{l}\text { Mean, } \\
\%\end{array}$ & S. D. \\
\hline $\begin{array}{l}\text { Not at all } \\
(0 \%)\end{array}$ & 3 & 10.00 & \multirow{5}{*}{43.33} & \multirow{5}{*}{21.71} & 0 & 3 & 10 & \multirow{5}{*}{4.80} & \multirow{5}{*}{2.76} \\
\hline $\begin{array}{l}\text { Seldom } \\
(1 \%-49 \%)\end{array}$ & 7 & 23.33 & & & $1-3$ & 5 & 16.67 & & \\
\hline $\begin{array}{l}\text { Half of their } \\
\text { time (50\%) }\end{array}$ & 15 & 50.00 & & & $4-6$ & 16 & 53.33 & & \\
\hline $\begin{array}{l}\text { Most of the } \\
\text { time } \\
(51 \%-99 \%)\end{array}$ & 5 & 16.67 & & & $7-9$ & 3 & 10.00 & & \\
\hline $\begin{array}{l}\text { All the time } \\
(100 \%)\end{array}$ & 0 & 0.00 & & & $\geq 10$ & 3 & 10.00 & & \\
\hline
\end{tabular}

high and it may be attributable to the complexity in green construction. Another possible reason is that more time is required by key project team members to fully understand the green technology systems which are incorporated into the design. In addition, it is necessary to ensure that the green elements are able to be integrated with the other building systems fully to prevent any conflicts during construction (Glavinich 2008; GreenBiz Group 2005; Kats et al. 2003).

Furthermore, as shown in Table 5, more than half of the respondents (16) reported that the amount of the schedule overrun of their projects ranged from 4 to $6 \%$ of the as-planned schedule. Also, the mean shown in Table 5 (4.8\%) indicated that the actual schedule of the green projects was delayed by an average of $4.8 \%$, which might be considered relatively severe. Thus, it can be of paramount concern of both clients and contractors as such delay has substantial effect on the overall project performance, ultimately reducing chances of producing successful projects.

\subsection{Recommendations for green construction schedule performance improvement}

The last section of the survey questionnaire inquired about respondents' sentiment in identifying possible recommendations to enhance green building construction project schedule performance. 14 possible solutions were included in the survey as a result of the review on several literatures (Alaghbari et al. 2007; Assaf et al. 1995; Beheiry et al. 2006; Chan, Kumaraswamy 1996; Kibert 2008; Korkmaz et al. 2010b; Lapinski et al. 2006; Magent et al. 2009; Nofera, Korkmaz 2010; Project Management Institute 2004; Smith 2003). The solutions were rated by the respondents with a Likert scale of 1 to 5 ( 1 being most relevant and 5 being least relevant), and Table 6 illustrates the ranking of the mean scores for the 14 listed solutions. 
Table 6. Recommendations for green construction schedule performance improvement

\begin{tabular}{|c|c|c|c|}
\hline Recommendations & Mean & S. D. & Rank \\
\hline $\begin{array}{l}\text { Ensure that the actual construction schedule and resources are seriously } \\
\text { monitored and reviewed so that the performance is in the line with as } \\
\text { planned to avoid the chances of cost overrun and disputes }\end{array}$ & 4.40 & 0.77 & 1 \\
\hline Ensure that design documents are produced on time & 4.37 & 1.03 & 2 \\
\hline $\begin{array}{l}\text { Ensure that contractors have the capability and the resources for con- } \\
\text { structing the project before awarding the tender }\end{array}$ & 4.37 & 1.00 & 2 \\
\hline $\begin{array}{l}\text { Check for mistakes and discrepancies in design documents to avoid redo- } \\
\text { ing of designs and drawing before submission for approval to avoid varia- } \\
\text { tions or necessary corrections }\end{array}$ & 4.17 & 0.95 & 4 \\
\hline $\begin{array}{l}\text { Alternative procurement method should be analysed to ensure it meets } \\
\text { the project requirements and complexity }\end{array}$ & 4.17 & 0.99 & 4 \\
\hline To minimize variation orders to avoid delays & 4.07 & 0.69 & 6 \\
\hline $\begin{array}{l}\text { Avoid delay in when reviewing and approval of documents, materials or } \\
\text { others are needed }\end{array}$ & 4.00 & 0.64 & 7 \\
\hline $\begin{array}{l}\text { Ensure that there is optimum number of labours to be assigned for indi- } \\
\text { vidual activities and motivate the workers to increase productivity }\end{array}$ & 3.97 & 0.81 & 8 \\
\hline $\begin{array}{l}\text { Administrative and technical staff should be appointed as soon as project } \\
\text { is awarded to facilitate the project is completed within specified time with } \\
\text { the required quality and estimated cost }\end{array}$ & 3.93 & 1.02 & 9 \\
\hline $\begin{array}{l}\text { Consultants should not delay the checking, reviewing and approving of } \\
\text { design documents leading to a delay in construction phase }\end{array}$ & 3.93 & 1.05 & 9 \\
\hline $\begin{array}{l}\text { Pay progress payment to the contractor timely to facilitate the contrac- } \\
\text { tors' ability to finance the work }\end{array}$ & 3.90 & 1.09 & 11 \\
\hline $\begin{array}{l}\text { Consultant should be flexibile in evaluating contractors work and balance } \\
\text { between the required quality with cost }\end{array}$ & 3.57 & 0.73 & 12 \\
\hline $\begin{array}{l}\text { Contractor should manage his financial resources and plan cash flow by } \\
\text { utilizing progress payment }\end{array}$ & 3.47 & 1.14 & 13 \\
\hline $\begin{array}{l}\text { Contractor should carry out a comprehensive economic analysis and } \\
\text { workable financial plans }\end{array}$ & 3.10 & 1.03 & 14 \\
\hline
\end{tabular}

The top 5 solutions are further discussed as follows:

Ensure that the actual construction schedule and resources are seriously monitored and reviewed so that the performance is in line with as planned to avoid chances of cost overrun and disputes: Project managers should check that the green building construction planning and scheduling are in perpetual processes during construction and the schedule plans correspond with the time to develop the work and resources to prevent cost overrun and disputes (Assaf et al. 1995). To ensure that the project schedule and resources are constantly monitored and reviewed, owners may deploy certain tools and techniques for schedule control. A schedule control system may be set up to define the procedures when changes occur in the project schedule, and performance measurements should be carried out to assess the degree of variations that took place (Project Management Institute 2004).

Ensure that design documents are produced on time: Design documents may include detailed construction drawings and specifications. When design documents are prepared to 
the required level, the design documents are used to secure a building permit, to competitively bid the work among qualified contractors and ultimately as the basis for the construction of the project. In addition, the design documents are submitted for approval and review by the local government building authority. As such, it is crucial that design documents are produced on time to facilitate the necessary actions and activities as mentioned in the former without impeding the project schedule.

Ensure that contractor have the capability and the resources for constructing the project before awarding the tender: According to Alaghbari et al. (2007) contractor related factors such as difficulties in financing projects, deficiencies in planning and updating schedule, and new construction methods implemented would have relatively high impact on project schedule performance. Considering that green construction requires new technologies, comprehensive planning and control, and experienced project team members, it is crucial to select contractors who can meet all the requirements. As a result, more comprehensive analysis on contractors' capacity should be performed before awarding necessary contracts. Development of a rigorous set of evaluation criteria that can be considered to screen contractors needs to be developed and implemented, based on specific requirements of green construction projects.

Check for mistakes and discrepancies in design documents to avoid redoing of designs and drawing before submission for approval to avoid variations or necessary corrections: When mistakes and discrepancies are discovered in design documents, redoing of designs and drawing requires extra time beyond the as-planned schedule to make the necessary changes (Assaf et al. 1995) and it will more often than not lead to poor time performance (Chan, Kumaraswamy 1996). When these mistakes and discrepancies are detected especially during the construction stage, variations leading to rework may take place thus giving rise to redundant work with additional cost pumped in to make the corrections.

Alternative procurement method should be analysed to ensure it meets the project requirements and complexity: Every procurement method has a different course of project development and involves different relationships between all the project team members (Nofera, Korkmaz 2010). As such, clients should analyse the project characteristics with care to select the appropriate procurement method as misinterpretation of project characteristics would probably lead to poor project performance and resulting in cost growth (Smith 2003). Due to the higher complexity of technical systems used in green building construction projects, the projects requires high levels of interdependency, communications and close partnerships with all the project participants during design stages (Kibert 2008; Magent et al. 2009; Korkmaz et al. 2010b). In addition, research had also shown that early involvement of owners would enable green building construction projects to achieve its green objectives at lower cost (Beheiry et al. 2006; Lapinski et al. 2006). Accordingly, it is vital to analyse alternative procurement methods to achieve better green building construction project performance.

\subsection{Limitations}

Although the analyses performed for this study provided meaningful finding and led to some productive discussions, one of the limitations is the small sample size as the survey 
only managed to obtain 30 completed sets. With a higher response rate, it would be able to project a more accurate industrial perspective with regard to the current green construction schedule performance in comparison with traditional building construction projects. Another limitation is only the consultants' and contractors' point of views was obtained as the client/developers of past green construction projects declined to respond to the research survey. Lastly, the respondents were reluctant to provide actual data of individual projects due to some confidentiality issues. Instead, the respondents went through their projects to investigate and compare actual and planned schedules of their projects. Then, they provided the average percentage of their companies.

\section{Conclusions and recommendations}

In April 2008, legislation mandated that all new buildings should achieve minimum Green Mark standard. Since new building construction projects are obliged to comply with Green Mark Scheme standards, it is therefore essential to look into how green building construction project performance can be managed more effectively. As such, this study aimed to address schedule performance of green building construction projects and provided some recommendations that may improve the performance.

The literature review performed for this study indicated that construction schedule performance was closely linked to construction cost and quality, and intrinsically, it was used as a benchmark to evaluate the performance of the entire project and efficiency of the project organization. In addition, it was widely discussed that green building construction projects required a more holistic and integrated approach in its delivery system as compared to traditional building construction projects. As green building construction required a more detailed design due to its complex technological characteristics, it called for greater efforts in communication and collaboration between project parties.

Furthermore, the analysis performed for this study revealed that on average, green building projects required about $8 \%$ more time to complete than traditional building construction projects with consideration of comparable characteristics. Also, it can be concluded that the planning and feasibility studies stage (15.70\%), and design development stage (17.15\%) were the two phases that were accountable for the increased use of time in order to achieve 'green' goals for green building construction projects. Similarly, the ranked project phases by the survey respondents revealed that design development stage (mean rank $=2.23$ ), schematic design (mean rank $=3.10$ ) as well as planning and feasibility stage (mean rank $=3.43$ ) had the highest impact on green building project schedule performance. In addition, the frequency of green building projects that experienced schedule overrun amounts to an average of $43 \%$ and the actual construction schedule would differ approximately $4.8 \%$ from the as-planned schedule which was attributed mainly by the design development phase.

Project participants may also consider the following recommendations drawn upon from this study in ensuring positive green construction project schedule performance: (1) to ensure that the actual construction schedule and resources are seriously monitored and reviewed so that the performance is in line with as planned to avoid chances of cost overrun and disputes; (2) to ensure that design documents are produced on time; (3) to ensure that 
contractors have the capability and the resources for constructing the project before awarding the tender; (4) to check for mistakes and discrepancies in design documents to avoid redoing of designs and drawing before submission for approval to avoid variations or necessary corrections; and (5) alternative procurement method should be analysed to ensure it meets the project requirements and complexity.

On the basis of the above findings, this study offers a benchmark for the industry to gauge the overall time duration required by a green building construction as compared to a traditional green building project of similar characteristics. Similarly, Clients should take into consideration the additional time required by the project phases when setting out the overall project schedule for green building projects.

For future studies, a construction time prediction model can be developed for a specific type of green building construction projects. The types of green projects that can be first considered for the development are industrial, housing, and commercial projects. Also, as project planning and feasibility studies together with project design stage in green building construction projects bear the highest impact on project schedule performance, one can also analyze the entire process of these two stages under various factors such as how different procurement method may affect project schedule to identify areas to enhance the project schedule performance.

\section{References}

Alaghbari, W.; Kadir, M. R. A.; Salim, A.; Ernawati. 2007. The significant factors causing delay of building construction projects in Malaysia, Engineering, Construction and Architectural Management 14(2): 192-206. http://dx.doi.org/10.1108/09699980710731308

Assaf, S. A.; AI-Khalil, M.; AI-Hazmi, M. 1995. Causes of delay in large building construction projects, Journal of Management in Engineering 11(2): 45-50. http://dx.doi.org/10.1061/(ASCE)0742-597X(1995)11:2(45)

Beheiry, S. M. A.; Chong. W. K.; Haas, C. T. 2006. Examining the business impact of owner commitment to sustainability, Journal of Construction Engineering and Management 132(4): 384-92. http://dx.doi.org/10.1061/(ASCE)0733-9364(2006)132:4(384)

Building and Construction Authority (BCA) 2008. Code for environmental sustainability of buildings (Version 1.0). Singapore: BCA. [online], [cited 12 Feb 2011]. Available from Internet: http://www. bca.gov.sg/EnvSusLegislation/others/Env_Sus_Code.pdf

Building and Construction Authority (BCA). 2009. $2^{\text {nd }}$ Green Building Masterplan. Singapore: BCA. [online], [cited 12 Feb 2011]. Available from Internet: http://www.bca.gov.sg/Newsroom/others/ pr270409.pdf

Building and Construction Authority (BCA). 2010. BCA clinches prestigious award from The Aspen Institute and sets higher Green Mark standards for new buildings. Singapore: BCA. [online], [cited 12 Feb 2011]. Available from Internet: http://www.greenmark.sg/news_August05.html

Chan, D.W. M.; Kumaraswamy, M. M. 1996. An evaluation of construction time performance in the building industry, Building and Environment 31(6): 569-578. http://dx.doi.org/10.1016/0360-1323(96)00031-5

Choi, C. 2009. Removing market barriers to green development: principles and action projects to promote widespread adoption of green development practices, Journal of Sustainable Real Estate 1(1): 107-138. 
CIRIA. 2001. Sustainable Construction Procurement: a guide to delivering environmentally responsible projects. London: CIRIA.

Enache-Pommer, E.; Horman, M. 2009. Key processes in the building delivery of green hospitals, in Building a sustainable future, ASCE, Reston, VA, 636-645.

Fortune, J.; White, D. 2006. Framing of project critical success factors by a systems model, International Journal of Project Management 24(1): 53-65. http://dx.doi.org/10.1016/j.ijproman.2005.07.004

Glavinich, T. E. 2008. Contractor's guide to green building construction. New Jersey: John Wiley \& Sons. http://dx.doi.org/10.1002/9780470259979

GreenBiz Group. 2005. Green building technique: a two-minute briefing on key business environmental issues. Oakland: GreenBiz Group Inc. [online], [cited 27 Feb 2011]. Available from Internet: http:// www.greenbiz.com/sites/default/files/document/O16F4162.pdf

Hwang, B. G.; Lim, E. S. 2013. Critical success factors for key players and objectives: case study of Singapore, ASCE Journal of Construction Engineering and Management 139(2): 204-215. http://dx.doi.org/10.1061/(ASCE)CO.1943-7862.0000597

Hwang, B. G.; Ng, W. J. 2013. Project management knowledge and skills for green construction: overcoming challenges, International Journal of Project Management 31(2): 272-284. http://dx.doi.org/10.1016/j.ijproman.2012.05.004

Hwang, B. G.; Tan, J. S. 2012. Green building project management: obstacles and solutions for sustainable development, Sustainable Development 20(5): 335-349. http://dx.doi.org/10.1002/sd.492

Hwang, B. G.; Zhao, X.; Ng, S. Y. 2013. Identifying the critical factors affecting schedule performance of public housing projects, Habitat International 38: 214-221. http://dx.doi.org/10.1016/j.habitatint.2012.06.008

Isik, Z.; Arditi, D.; Dikmen, I.; Birgonul, M. T. 2009. Impact of corporate strengths/weaknesses on project management competencies, International Journal of Project Management 27(6): 629-637. http://dx.doi.org/10.1016/j.ijproman.2008.10.002

Iyer, K. C.; Jha, K. N. 2006. Critical factors affecting schedule performance: evidence from Indian construction projects, Journal of Construction Engineering and Management 132(8): 871-881. http://dx.doi.org/10.1061/(ASCE)0733-9364(2006)132:8(871)

Kats, G.; Alevantis, L.; Berman, A.; Mills, E.; Berkeley, L.; Perlman, J. 2003. The costs and financial benefits of green buildings. A Report to California's Sustainable Building Task Force.

Kats, G. 2010. Greening our built world: costs, benefits, and strategies. New York: Island Press.

Kibert, C. J. 2008. Sustainable construction: green building design and delivery. New Jersey: John Wiley \& Sons.

Korkmaz, S.; Riley, D.; Horman, M. 2010a. Piloting evaluation metrics for sustainable, high performance building project delivery, Journal of Construction Engineering and Management 136(8): 877-885. http://dx.doi.org/10.1061/(ASCE)CO.1943-7862.0000195

Korkmaz, S.; Messner, J. I.; Riley, D. R.; Magent, C. 2010b. High-performance green building design process modeling and integrated use of visualization tools, Journal of Architectural Engineering 16(1): 37-45. http://dx.doi.org/10.1061/(ASCE)1076-0431(2010)16:1(37)

Kua, H. W. 2011. Integrated sustainability policies for China's cement industry - a case study approach, in environmental change in Asia: challenges and prospects. Pearson, Singapore.

Kubba, S. 2010. Green construction project management and cost oversight. U.S.A: Elsevier.

Lapinski, A. R.; Horman, M. J.; Riley, D. R. 2006. Lean processes for sustainable project delivery, Journal of Construction Engineering and Management 132(10): 1083-1091.

http://dx.doi.org/10.1061/(ASCE)0733-9364(2006)132:10(1083) 
Li, Y. Y.; Chen, P.; Chew, A. S.; Teo, C. C.; Ding, R. G. 2011. Critical project management factors of AEC firms for delivering green building projects in Singapore, Journal of Construction Engineering and Management 137(12): 1153-1163. http://dx.doi.org/10.1061/(ASCE)CO.1943-7862.0000370

Magent, C. S.; Korkmaz, S.; Klotz, L. E.; Riley, D. R. 2009. A design process evaluation method for sustainable buildings, Architectural Engineering and Design Management 5: 62-74. http://dx.doi.org/10.3763/aedm.2009.0907

Male, S. 1988. Faster building for commerce. UK: National Economic Development Office.

Nguyen, D. L.; Ogunlana, S.; Truong, Q.; Ka, C. L. 2004. Large construction projects in developing countries: a case study from Vietnam, International Journal of Project Management 22(7): 553-561. http://dx.doi.org/10.1016/j.ijproman.2004.03.004

Nofera, W.; Korkmaz, S. 2010. Design process integration for sustainable, high performance buildings, in Engineering Project Organizations Conference, South Lake Tahoe, CA.

Ogunlana, S. O.; Promkuntong, K.; Jearkjirm, V. 1996. Construction delays in a fast growing economy: comparing Thailand with other economies, International Journal of Project Management 14(1): 37-45. http://dx.doi.org/10.1016/0263-7863(95)00052-6

Project Management Institute 2004. A guide to the project management body of knowledge (PMBOK Guide) Third Edition. USA: Project Management Institute

Singapore Green Building Council (SGBC). 2009. A Strategic plan. Singapore: SGBC. [online], [cited 27 Feb 2011]. Available from Internet: http://www.sgbc.sg/images/uploads/SGBC_Strategic_Plan_v5.pdf

Smith, A. 2003. Building momentum: national trends and prospects for high performance green buildings. Green Building Roundtable and Prepared for the U.S. Senate Committee on Environment and Public Works (U.S. Green Building Council). Washington, D.C.

Tagaza, E.; Wilson, J. L. 2004. Green buildings: drivers and barriers e lessons learned from five melbourne developments, in Report Prepared for Building Commission by University of Melbourne and Business Outlook and Evaluation.

The Business Times. 2010. Making Their Mark on The Environment. Singapore: Environmental Directory. [online], [cited 10 December 2011]. Available from Internet: http://www.greensingapore.com/Singlenews.aspx?DirID $=55 \&$ rec_code $=591674$

Tobias, C. 2010. Outlook for carbon markets uncertain, in Eco-Business. [online], [cited 10 December 2011]. Available from Internet: http://www.eco-business.com/blog/outlook-carbon-markets-uncertain/

Zhang, X.; Platten, A.; Shen, L. 2011. Green property development practice in China: costs and barriers, Building and Environment 46(11): 2153-2160.

Bon-Gang HWANG is an Assistant Professor in the Department of Building at National University of Singapore. He has several years of experience in the construction industry in South Korea, USA, and Singapore. His current research interests are in the areas of management strategies and innovations for green construction projects, performance assessment and improvement, and risk management.

Lay Peng LEONG graduated from the National University of Singapore in 2011 in Project and Facilities Management. She had been with EC Harris Singapore Pte Ltd, Singapore as an Cost Control Executive since 2011 .

Young-Ki HUH is an Associate Professor in the Department of Architectural Engineering at the Pusan National University, Republic of Korea. He is a member of Korea Institute Construction Engineering and Management (KICEM) and Architectural Institute of Korea. His research interests include project success factors, productivity analysis, cost estimation of a public housing project, and standardized cost estimation system for public sector. 